\title{
A Critical Essay to the selected text - "Araby" What makes the protagonist in "Araby" a lonely person? Has he gained anything from his journey?
}

\author{
Charles Ko \\ City University of Hong Kong \\ E-mail: ko_kashing@hotmail.com
}

Doi:10.7575/aiac.alls.v.4n.2p.93

URL: http://dx.doi.org/10.7575/aiac.alls.v.4n.2p.93
Received: 05/04/2013

Accepted: 05/06/2013

\begin{abstract}
The present study has been covered an overview and the analysis of the short story "Araby" to find out what makes the protagonist a lonely person, by plot points, characters and themes, and then it has been included a discussion about the gain of the protagonist from the journey. The story starts in the drab life that people live on North Richmond Street. The narrator, a boy who is unnamed, believed to be at the age of around twelve (Cummings), describes the street where he lives at the very beginning of the story. He then thinks about the priest who died in the house before his family moved in, and the games that he and his friends played in the street, recalling how they were running through the back lanes of the houses and hid in the shadows to avoid people in their neighborhood, especially the boy's uncle, and the sister of his friend Mangan. Mangan's sister is always in the thoughts of the narrator although they talk little. The paper enables us to have an opportunity to reflect on our life: if we reflect the "gain" again in the more critical direction, we should not regard the loss of innocence as any gain: the innocence that we cannot easily retrieve it from society must be protected before it is lost; to a large extent, innocence may not be negative if we consider it as a source of happiness.
\end{abstract}

Keywords: Araby, bazaar

\section{Introduction}

The story starts in the drab life that people live on North Richmond Street. The narrator, a boy who is unnamed, believed to be at the age of around twelve (Cummings), describes the street where he lives at the very beginning of the story. He then thinks about the priest who died in the house before his family moved in, and the games that he and his friends played in the street, recalling how they were running through the back lanes of the houses and hid in the shadows to avoid people in their neighborhood, especially the boy's uncle, and the sister of his friend Mangan. Mangan's sister is always in the thoughts of the narrator although they talk little. One day's morning Mangan's sister asks the protagonist whether he plans to go to Araby. The narrator promises to bring her something from the bazaar. On Saturday's morning the narrator reminds his uncle that he will go to the bazaar at night so he requests his uncle to return home early so that he can get the train fare on time. However, the uncle returns home late in the evening. Before he comes back the boy endures the time passing impatiently. Finally the uncle returns at 9 p.m., that he has forgotten the narrator's plans of journey to Araby. The uncle then gives the narrator the money. Eventually he arrives at the bazaar just before 10 p.m. while it is starting to close down. He approaches one stall that is still open but does not buy anything at last. With nothing for Mangan's sister, the narrator stands angrily in the deserted bazaar as the lights go out. The work "Araby" includes the protagonist (the young boy) and Mangan's sister to be the main characters. Although "Araby" is only a short story, there have already been a number of established themes spread throughout the story meaningfully and logically, with romantic moments, and with reflective views. These themes such as coming of age, the dangers of idealization, the Catholic Church's influence to make Dublin a place of asceticism where desire and sensuality are seen as immoral_Coulthard 97) and the loss of innocence etc. build the whole story. At the beginning of this essay above, I have provided an overview of story. In the middle session, it is written the analysis of the story especially in terms of plot points, characters, and themes, addressing the questions raised by the topic of this essay. In this essay, it will only be focused on the themes of alienation and loneliness, coming of age and change and transformation.

\section{Analysis}

Many symbolizing devices have been adopted in "Araby" by James Joyce at many places of the story. The name, Araby, itself has already implied the Arabic exoticism and the unlimited and unique charm of the Middle East, "the mystique and allure of the Middle East" (Cummings), at the same time symbolizing the target of life of the protagonist, and the discovery of the ideality, that inevitably involve the process which leads to the loneliness to himself; but at least he will gain something about the reality until the age that he understands the inevitable conflict between the ideality and reality, and will think more maturely beyond the innocence in the past. 


\section{Plot Points}

In rising action, James Joyce plays up the protagonist's thirst for "Araby", and for climax, it is narrated that he arrives in the bazaar eventually, but the bazaar is not the place that he wanted in his mind, as follows:

Nearly all the stalls were closed and the greater part of the hall was in darkness. I recognised a silence like that which pervades a church after a service. I walked in to the centre of the bazaar timidly. (Joyce 355)

Here, the place Araby in "darkness" symbolizes the Irish society at that time, fulfilling the atmosphere of asceticism, that the reality is greatly contradicted with the ideal romance in the protagonist's mind. When the protagonist discovers his dream and the things that he yearns for in Araby are all just within a dusky market, the narrator is illustrating to us that the young boy's perfect romance and ideal dream are both destroyed thoroughly by the cruel reality. And at that time, he goes to the bazaar alone, that he cannot share what his instant feelings to others at once. This is an oppression which makes the protagonist be even lonely in mind as a result. In "Araby", the first-person narrator, James Joyce, does not describe explicitly in words how the protagonist feels, instead he leads the readers to experience it by themselves, to enter the protagonist's affection through what are seen from his eyes, heard from ears. For instance:

[...] I was alone at the railing. She held one of the spikes, bowing her head toward me. The light from the lamp opposite our door caught the white curve of her neck, lit up her hair that rested there and, falling, lit up the hand upon the railing. It fell over one side of her dress and caught the white border of a petticoat, just visible as she stood at ease. (Joyce 351)

Through Joyce's first-person narration, the reader is immersed into the thoughts of the young boy. This plot point can obviously show that the narrator enjoys being alone, that it is his character in fact. In falling action by Joyce, from "I took my seat in a third-class carriage of a deserted train [...] I remain alone in the bare carriage" (354), the narrator's unfulfilling romance has been foreshadowed by the use of words "deserted" and "alone", and in literature this usage of vocabulary further develops the loneliness of the protagonist in front of the readers.

\section{Characters}

Among these I found a few paper-covered books, the pages of which were curled and damp: The Abbot, by Walter Scott, The Devout Communicant and The Memoirs of Vidocq. I like the last best because its leaves were yellow. (Joyce 351) (not bold in original piece)

This excerpt, especially the last sentence (in bold), reflects the boy’s hobby. By symbolization, “yellow” symbolizes "old”, it marks that he loves old things, and he may have a classical collection habit like an elder man likes to collect classic objects. The narrator makes the protagonist a "boring" boy compared with the typical children at the same age (i.e. twelve years old (Cummings)), that he is made to be special within his peers. It is narrated in setting that he has the interest different from the one of his peer, so he may fail to concern the general issues of the age group that he should belong to. In turn he will lose participations in group activities with friends because of the ignorance by others of his lack of the common topics when chatting with them, and due to this point, he may further hide himself and decrease the social interaction, and further he would consciously agree that he should be a lonely person because he thinks this is his own character, that in the end he will not attempt to find solutions to overcome the loneliness.

Besides, the character of Mangan's sister is not set to be a very sensible girl; as a result she cannot realize the love of the protagonist through their conversation, which leads him to be further isolated. Furthermore, where he lives in is not a typical family, not with mother and father. The narrator may not trust his uncle and aunt as thoroughly as how the normal children trust their father and mother. The social context results in his subconscious reaction, to escape from talking to them. Moreover, the uncle and aunt are not circumspect and attentive enough, that this also contributes to the loneliness of the protagonist due to the ignorance of his recent feelings by them.

\section{Themes}

\section{The Coming of Age}

In exposition, it is narrated that the protagonist used to be a child enjoying to play with his friends in the street. Then the story development demonstrates how his pursuit of ideality and love ultimately leads to his downfall: his idealized vision of Araby is destroyed, and he feels shameful and angry for his vanity; nevertheless he exits the bazaar with the loss of idealized image of Mangan's sister and the love eventually: "Gazing up into the darkness I saw myself as a creature driven and derided by vanity; and my eyes burned with anguish and anger (Joyce 355)". It is the outcome derived from the transition of ages between childhood and adolescence, that the narrator makes the protagonist be coming to the adolescence in term of age, which is the typical period of having "loneliness" from educational psychological perspectives: early in adolescence, cognitive developments result in greater self-awareness, greater awareness of others and their thoughts and judgments; adolescents experience a significant shift from the simple, concrete, and global self-descriptions typical of young children; as children, they defined themselves with physical traits whereas as adolescents, they define themselves based on their values, thoughts and opinions (Carlson). As a result, the protagonist further insists that being lonely is his choice but not because he is discriminated by peers, to protect his self-esteem and avoid the attacks from the honest negative judgments by his family.

Loneliness, and Loss of innocence

The narrator tries to make the protagonist in "Araby" a lonely person, but does not fail to let the readers reflect on the things that he has gained from his journey. 
From the whole story, the narrator never shares his feelings about Mangan's sister with uncle and aunt, friends, and Mangan and his sister, which constitutes the theme of loneliness. The theme is presented by the action that the narrator isolates himself from everyone. Finally, "when he suddenly realizes how foolish he has been, his anger at himself is intensified by his alienation from everyone and the resulting feeling of isolation" ("Scribd" 3). After the journey to Araby, he realizes that the reality is not like what was in his mind. In resolution of the story, it is depicted that the narrator experiences there is always the conflict of ideality and reality. The journey brings him a flash of an instant that lets him grow emotionally, changing from an innocent young boy to a disillusioned adolescent. His feelings "anguish" and "anger" (Joyce 355) reflect that he has learnt something about the adulthood. However, some "Araby" analysist put emphasis on the loss of satisfaction more than the gain of life experience from the journey:

This insight occurs through what Joyce called an "epiphany," which is a moment of intense insight and selfunderstanding. Although the narrator suddenly understands that he has allowed his feelings to get carried away, this understanding makes him neither happy nor satisfied. If anything, he is very angry at himself for acting foolishly. ("Scribd" 4)

But at least the protagonist realizes that there is always the conflict between the ideality and reality, which is worth to be known and experienced in the journey of life. This realization marks the beginning of his maturation from a child into an adult, which is usually regarded as a gain, from the eyes of the parents from middle class, that this view is different from what is seen from the innocence eye of the protagonist.

\section{Conclusion}

This essay has been covered an overview and the analysis of the short story "Araby" to find out what makes the protagonist a lonely person, by plot points, characters and themes, and then it has been included a discussion about the gain of the protagonist from the journey. If we reflect the "gain" again in the more critical direction, we should not regard the loss of innocence as any gain: the innocence that we cannot easily retrieve it from society must be protected before it is lost; to a large extent, innocence may not be negative if we consider it as a source of happiness. In other words, if the story can include an ending that the boy suddenly wants to be sociable and get rid of loneliness after experiencing the pain from journey, at the same time his innocence is kept, then readers should be more convinced of his gain from the journey.

\section{Reference}

Araby (James Joyce 1914) Criticsim. 2008: 3. 21 Oct. 2012. <http://zh.scribd.com/doc/3310655/Araby-James-Joyce1914>.

Araby (James Joyce 1914) Criticsim. 2008: 4. 21 Oct. 2012. <http://zh.scribd.com/doc/3310655/Araby-James-Joyce1914>.

Coulthard, A.R. "Joyce's Araby." Academic Search Premier. Web. Explicator 52.2 (1994): 97.23 Aug. 2012.

Carlson, Neil R. Psychology: the science of behaviour. Toronto, Ontario: Pearson Education Canada. 2010.

Cummings, Michael J. A Short Story by James Joyce (1882-1941) - A Study Guide. 2010. 11 Oct. 2012. $<\mathrm{http}: / /$ www.cummingsstudyguides.net/Guides5/Araby.html $>$.

Joyce, James. “Araby." Dubliners. London: Grant Richards. 1914. 